\title{
WATER QUALITY MONITORING IN URBAN BASINS AS SUPPORT FOR WATER RESOURCES MANAGEMENT: A CASE STUDY FROM SOUTHERN BRAZIL
}

\author{
NÍCOLAS R. FINKLER ${ }^{1}$, JARDEL COCCONI², TAISON A. BORTOLIN ${ }^{3}$, LUDMÍLSON A \\ MENDES $^{4}$, VANIA E. SCHNEIDER ${ }^{3}$ \\ ${ }^{1}$ University of São Paulo, Brazil \\ ${ }^{2}$ Federal University of Santa Catarina, Brazil \\ ${ }^{3}$ University of Caxias do Sul, Brazil \\ ${ }^{4}$ Federal University of Sergipe, Brazil
}

\begin{abstract}
One of the main challenges of water management in developing countries is to control the impact of the urban environment on the natural environment. Identifying sources of pollution in an urban watershed is a critical first step towards providing more integrated environmental planning, proper wastewater disposal and public water supplying. Thus, in this study we assessed 5-year water quality data from six urban river basins in Southern Brazil. In addition to the principal component analysis (PCA), three indexes were evaluated individually: Water Quality Index (WQI), Toxicity Index (TI) and CCME WQI framework (CCME WQI). In order to evaluate the effect of land use, the monitoring sites were assessed according to the urbanization criteria. The application of PCA revealed the existence of six components, explaining $73.78 \%$ of data variation. The component that explains most of the variation in water quality $(30.80 \%)$ is associated with domestic wastewater. The second component showed a strong dependence (29.44\%) on industrial activities such as electroplating and metalworking in determining the water quality, while the other components are related to certain industrial and agricultural activities. Likewise, the application of WQIs demonstrated similar results to the PCA. WQI and TI showed scenarios of concern regarding public supply. CCME WQI presented a significant disparity between the assessed watersheds and the Brazilian legal framework goals. Studies in this field significantly contribute to the establishment of environmental licensing criteria, by demonstrating patterns and environmental features. In addition to it, one can identify which watersheds demand greater attention with respect to control and recovery of proper environmental conditions. Furthermore, it can provide support for revisions in urban and watershed planning, especially in qualitative aspects eluding conflicts over water use in future scenarios. Keywords: Caxias do Sul, multivariate analysis, Toxicity Index, urban waters, Water Quality Index, water resources management
\end{abstract}

\section{INTRODUCTION}

Water quality pollution often works as a result of multiple land use purposes in a water body, and such pollution sources can be classified as point or diffuse sources. Whereas point source pollution is easily identified (e.g. an industrial effluent contribution), non-point sources (e.g. agrochemical drainage or urban runoff) are of mapping difficulty, when one does attribute contamination to a single root [1-4].

The spatiotemporal evaluation of water quality in an urban watershed provides more integrated planning with regard to environmental issues and public water supply. It also allows better understanding of the relationships between land use and water embedment, and to further identification of point source pollution. Technical data for non-point source recognition and mapping also become reliable, allowing an incisive discussion over the multiple water demands and uses [5-8].

In this context, at the beginning of 2009 the project 'Quali-quantitative Monitoring of Urban Watersheds in Caxias do Sul, RS' was created. The main goal was to collect and process water quality data from urban waters in the municipality as well as to, simultaneously, 
detail land use and cover of the region, seeking to link these topics in annual reports. There were essentially three campaigns for monitoring and sampling, the last of which was conducted in July 2014.

The present study aims at showing the current water resource diagnosis in the city of Caxias do Sul by calculating and reviewing Water Quality Index (WQI), Toxicity Index (TI) and CCME WQI framework (CCME WQI), as well as some statistical results through principal component analysis (PCA) of the monitoring data.

\section{MATERIALS AND METHODS}

\subsection{Study area}

The city of Caxias do Sul is located in the southern Brazilian state of Rio Grande do Sul, metropolitan region of Serra Gaúcha, with a total area of $1,644.3 \mathrm{~km}^{2}$. The estimated population of the city in 2014 was 470,223 inhabitants, $96 \%$ of which reside in urban areas and $4 \%$ in the countryside. Demographic density is estimated to be 265 inhabitants $/ \mathrm{km}^{2}$. It is possible to observe a wide range of economic activities in the Serra Gaúcha region: mechanical engineering industries; textile sector; plastic manufacturing industries; horticultural farming; pig farming; and poultry and livestock [9].

Water parting and topographical limits split the area of the city into two water basins: the Taquari-Antas Watershed and the Caí Watershed. The total drainage areas for the main urban catchments are listed in Table 1.

Table 2 presents the framework of waters from each watershed within the city limits considering the already established classes and water uses according to Ref. [10]. Classes range

Table 1: Drainage areas for the main urban catchments (*monitored).

\begin{tabular}{lccccc}
\hline Sub-basins & $\begin{array}{l}\text { Microbasin } \\
\text { area }\left(\mathbf{k m}^{2}\right)\end{array}$ & $\begin{array}{l}\text { Urban area } \\
\left(\mathbf{k m}^{2}\right)\end{array}$ & $\begin{array}{l}\text { \% of area } \\
\text { in urban } \\
\text { perimeter }\end{array}$ & $\begin{array}{l}\text { \% of drainage } \\
\text { area in urban } \\
\text { perimeter }\end{array}$ & $\begin{array}{l}\text { \% urban } \\
\text { perimeter in } \\
\text { basin area }\end{array}$ \\
\hline $\begin{array}{l}\text { Faxinal } \\
\text { Stream* }\end{array}$ & 118.9 & 26.53 & 22 & 11 & Antas River 65 \\
$\begin{array}{l}\text { São Marcos } \\
\text { River }\end{array}$ & 403.54 & 26.53 & 7 & 11 & \\
\hline $\begin{array}{l}\text { Herval } \\
\text { Stream }\end{array}$ & 77.59 & 70.872 & 91 & 30 & \\
$\begin{array}{l}\text { Maestra } \\
\text { Stream* }\end{array}$ & 53.68 & 48.49 & 90.33 & 20 & \\
$\begin{array}{l}\text { Samuara } \\
\text { Stream }\end{array}$ & 22.95 & 17.35 & 76 & 7 & \\
$\begin{array}{l}\text { Curuçu } \\
\text { Stream }\end{array}$ & 86.511 & 3.869 & 0 & 2 & \\
Tega River* & 291.47 & 123.231 & 42 & 52 & \\
\hline Biazu Stream & 48,74 & 3.88 & 8 & 2 & \\
\hline $\begin{array}{l}\text { Loreto } \\
\text { Stream }\end{array}$ & 30.49 & 2.35 & 8 & 1 & \\
Ouro Stream & 153.53 & 2.36 & 2 & & \\
\hline
\end{tabular}

(Continued) 
Table 1: (Continued)

\begin{tabular}{lccccc}
\hline Sub-basins & $\begin{array}{l}\text { Microbasin } \\
\text { area }\left(\mathbf{k m}^{2}\right)\end{array}$ & $\begin{array}{l}\text { Urban area } \\
\left(\mathbf{k m}^{2}\right)\end{array}$ & $\begin{array}{l}\text { \% of area } \\
\text { in urban } \\
\text { perimeter }\end{array}$ & $\begin{array}{l}\text { \% of drainage } \\
\text { area in urban } \\
\text { perimeter }\end{array}$ & $\begin{array}{l}\text { \% urban } \\
\text { perimeter in } \\
\text { basin area }\end{array}$ \\
\hline $\begin{array}{l}\text { Pinhal } \\
\text { Stream* }\end{array}$ & 87.08 & 28.52 & 33 & 12 & Caí River 35 \\
Belo Stream* & 162.44 & 50.88 & 31 & 21 & \\
$\begin{array}{l}\text { Espelho } \\
\text { Stream }\end{array}$ & 46.35 & 15.2 & 33 & 6 & \\
$\begin{array}{l}\text { Pena Branca } \\
\text { Stream }\end{array}$ & 22.01 & 14.76 & 67 & 6 & \\
Piaí River* & 328.7 & 29.96 & 9 & 13 & \\
\hline
\end{tabular}

Table 2: Framework targets for watersheds.

\begin{tabular}{|c|c|c|c|c|}
\hline \multirow{2}{*}{\multicolumn{2}{|c|}{ Watershed }} & \multicolumn{2}{|c|}{ Framework targets } & \multirow[t]{2}{*}{ Legislation (resolution) } \\
\hline & & Intermediate & Final & \\
\hline \multicolumn{2}{|c|}{ Belo Stream } & Class 3 & Class 2 & CRH 50 \\
\hline \multicolumn{2}{|c|}{ Pinhal Stream } & Class 3 & Class 3 & CRH 50 \\
\hline \multicolumn{2}{|c|}{ Faxinal Stream } & Class 3 & Class 2 & CRH 121 \\
\hline \multicolumn{2}{|c|}{ Maestra Stream } & Class 2 & Class 2 & CRH 121 \\
\hline \multirow[t]{3}{*}{ Piaí River } & Stretch E & Class 1 & Class 1 & CRH 50 \\
\hline & Stretch W & Class 3 & Class 3 & \\
\hline & ver & Class 2 & Class 2 & CRH 121 \\
\hline
\end{tabular}

from 1 to 4 according to the pollution levels and restrictions of the water. Class 1 allows less restrictive water uses and presents significantly better water quality than class 4 . Also, local legislation must consider improvement of the water bodies as targets to be achieved within the given years. The embodiment targets for the sub-basins inserted in both the Taquari-Antas and Caí Watershed are shown in Table 2 [11, 12].

In order to properly meet the goals of the monitoring project and to improve its importance over the years, the sampling point grid has been changed constantly. Figure 1 shows the watersheds assayed and the totality of sampling points from all monitoring campaigns, as well as spatial classifications with regard to the urbanization criteria (Table 3).

\subsection{Tools for results analysis}

This study analysed 28 physical, chemical and microbiological variables. During the three phases of the project, a volume of about 18,000 results were generated in the analysed watersheds. To enable the understanding of the results, multivariate statistical techniques and WQIs were used, whose calculation methodologies are presented later. 


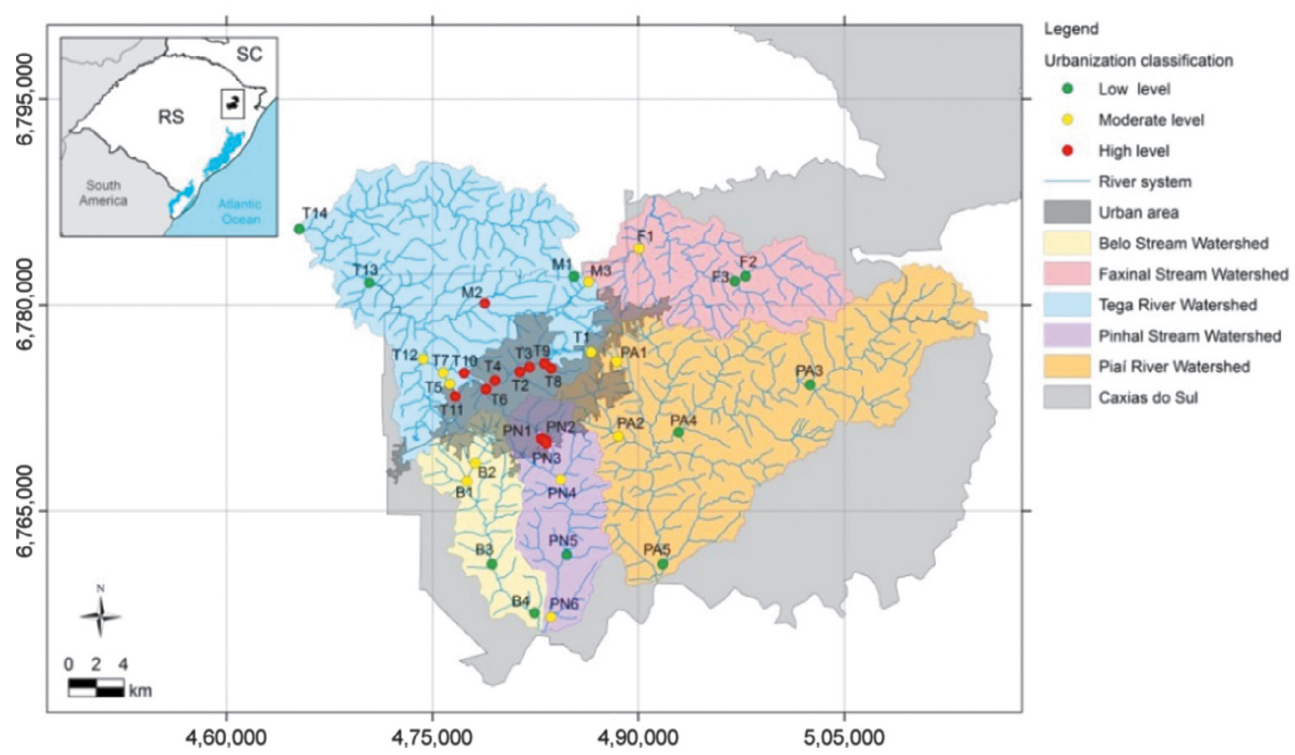

Figure 1: Location and characterization of sampling points in each watershed (T, Tega; PN, Pinhal; B, Belo; M, Maestra; F, Faxinal; PA, Piaí).

Table 3: Criteria for spatial classification of the monitoring points.

\begin{tabular}{ll}
\hline \multicolumn{1}{c}{ Classification } & \multicolumn{1}{c}{ Features } \\
\hline High level of urbanization & Heavily urban surroundings \\
& Significant changes of the natural landscape \\
& Industrial sector $(>100 \mathrm{~m})$ \\
\hline Moderate level of urbanization & Moderate urban surroundings \\
& Moderate changes of the natural landscape \\
& Industrial sector $(>1 \mathrm{~km})$ \\
\hline Low level of urbanization & Small urban centres \\
& Little or no change of the natural landscape \\
& Absence of the industrial sector $(1 \mathrm{~km})$ \\
\hline
\end{tabular}

PCA has been widely used in the interpretation of complex water quality data and other environmental problems. PCA may be defined as a multivariate analysis technique that transforms the set of data into a new system of variables. Within this new arrangement, the principal components (PC) are linear functions of the original set of variables, which are not correlated. The projection of the greatest variation from the sample generates the first PC, the projection of the second greatest variation, the second PC and so on [13].

The application of PCA has been an effective tool in water resources management and pollution control, in addition to being useful in identifying possible factors of influence in river basins [14]. Some researchers [6,14-16] faced a large set of data and found PCA as a suitable tool in the evaluation and identification of water quality. 
WQI was initially created by the National Sanitation Foundation of the United States and modified by the State Sanitation Company of São Paulo (CETESB). It is calculated by the product operator equation, using the curves of importance of nine water quality parameters developed by CETESB [17], which represent the variation in the water quality produced by the possible measures of the parameter. The results are compared in a water quality classification table, with value intervals (Table 4). Studies $[2,4,5,8]$ used the index to assess water quality.

An index often used to represent the potential toxicity of a particular water sample is the TI. According to Ref. [18], a form of TI classification used by the Institute of Water Management of Minas Gerais characterized toxicity as low, medium or high. The evaluation is performed by comparing the concentrations obtained with the standards set by the CONAMA Resolution 357 [10]. The calculation of TI in this study considers the following parameters: ammoniacal nitrogen, nitrates, phenol, cyanides, lead, chromium, nickel and zinc. The worst situation identified at the point of sampling, considering all the parameters used in the TI calculation, defines the contamination category of the period in consideration [18]. The classification range is presented in Table 5.

The CCME WQI was developed by the Canadian Council of Ministers of the Environment [19], with the aim of providing a tool for evaluating water quality data, incorporating the most convenient parameters from each institution and ease of understanding. Studies such as [20-23] used this methodology in the assessment of water quality for various uses. The index was proposed by Amaro [24] in the assessment of water quality in the PCJ (Piracicaba, Capivari and Jundiaí rivers, SP - Brazil) basins and is currently used by the National Water Agency (ANA - Brazil) to evaluate compliance with the established quality objectives from Brazilian rivers [25]. Three ranges of values are established for the index, which characterize compliance with water quality objectives defined by the framework, as shown in Table 6.

Table 4: Water quality classification.

\begin{tabular}{lc}
\hline Category & Values \\
\hline Excellent & $90<\mathrm{WQI} \leq 100$ \\
Good & $70<\mathrm{WQI} \leq 90$ \\
Regular & $50<\mathrm{WQI} \leq 70$ \\
Poor & $25<\mathrm{WQI} \leq 50$ \\
Very poor & $\mathrm{WQI} \leq 25$ \\
\hline
\end{tabular}

Table 5: Interpretation of the conditions for toxicity contamination.

\begin{tabular}{lll}
\hline Contamination & Representative colour & $\begin{array}{l}\text { Relationship between the concentration } \\
\text { and the class threshold value (quality } \\
\text { standard) }\end{array}$ \\
\hline Low & Green & $\mathrm{C} \leq 1,2 . \mathrm{P}$ \\
Mid & Yellow & $1,2 . \mathrm{P}<\mathrm{C} \leq 2 . \mathrm{P}$ \\
High & Red & $\mathrm{C}>2 . \mathrm{P}$ \\
\hline
\end{tabular}

$\mathrm{P}=$ standard value (class limit), according to Ref. [10]; $\mathrm{C}=$ concentration of the parameter. 
Table 6: CCME WQI classification categories.

\begin{tabular}{ll}
\hline Categories & \multicolumn{1}{c}{ Description } \\
\hline $80 \leq$ CCME WQI $\leq 100$ & $\begin{array}{l}\text { Most or all measurements are within the quality } \\
\text { standards defined by the framework } \\
\text { Compliant }\end{array}$ \\
$\begin{array}{l}\text { Measurements are often at odds with the quality } \\
\text { Outlying }\end{array}$ & $\begin{array}{l}\text { Most or all of the measurements are not in compli- } \\
\text { CCME WQI }<45\end{array}$ \\
Non-compliant & ance with the limits of the framework class \\
\hline
\end{tabular}

Among the quality parameters that were sampled, 14 are defined in the CONAMA Resolution 357 [10] within the maximum or minimum limits of the framework, depending on the type of use of the bodies of water. In order to calculate the CCME WQI in this study, the intermediate quality goal established by the aforementioned resolutions was considered for each river basin, as outlined in Table 2 .

The WQI and TI results are presented based on the spatial division considering urbanization criteria (Table 3), as well as the breakdown by monitoring phase. The results of the CCME WQI are presented by river basin, representing the frequency that each category obtained at the end of the monitoring period.

\section{RESULTS AND DISCUSSION}

The PCA revealed the existence of six PCs, explaining $73.78 \%$ of total variation (Table 7). We used 18 water quality parameters, which are present in most of the PCA analysis used as baseline studies. Reference [26] classified the factorial loads corresponding to the absolute composition of the PC in values ranging from significant $(>0.75)$, medium $(0.50-0.75)$ and irrelevant $(0.30-0.50)$. In water quality parameters study, which present great data variability, values greater than 0.50 are commonly used to define PC loads $[5,7,27]$.

The analysis of components generated with the PCA suggests that the variation in the water quality stems mostly from domestic sewage discharges without proper treatment. It is possible to identify within the composition of $\mathrm{PC} 1$ the parameters of conductivity, total Kjeldahl nitrogen, ammoniacal nitrogen, total phosphorus, biochemical oxygen demand (BOD), thermotolerant coliforms and chemical oxygen demand (COD), which correspond to $30.80 \%$ of the variation of the data and are strictly related to domestic pollution.

PC2, PC3 and PC4, corresponding to $29.44 \%$ of the total variation, had as heavier weights the metals used in the most representative industrial activities in the region, electroplating and metal mechanics. Furthermore, the presence of COD composing PC2 and pH in PC3 suggests that there is a correlation between $\mathrm{COD}, \mathrm{pH}$ and the presence of these metals in the determination of the water quality in the city rivers.

PC5 and PC6, composed of cyanide and phenol parameters, respectively, indicate that industrial activities such as metallurgy, plastics manufacturing and electrical components, as well as the food industry, influence the determination of water quality. There is still a parcel related to the use of pesticides, which has such elements in its composition. It is worth noting the toxicity these components present to aquatic ecosystems, being the implementation of control systems important, bearing in mind the potential contamination to the aforementioned. 
Table 7: Factorial loads with rotation of the variables for the identified PC.

\begin{tabular}{|c|c|c|c|c|c|c|}
\hline Parameter & $\begin{array}{l}\text { Principal } \\
\text { component }\end{array}$ & & & & & \\
\hline & 1 & 2 & 3 & 4 & 5 & 6 \\
\hline Conductivity & 0.959 & 0.056 & 0.067 & -0.004 & 0.009 & -0.076 \\
\hline $\begin{array}{l}\text { Total Kjeldahl } \\
\text { nitrogen }\end{array}$ & 0.954 & 0.065 & 0.108 & -0.037 & 0.025 & -0.113 \\
\hline $\begin{array}{l}\text { Ammoniacal } \\
\text { nitrogen }\end{array}$ & 0.918 & 0.007 & 0.121 & -0.073 & -0.013 & -0.162 \\
\hline Total phosphorus & 0.866 & 0.239 & -0.08 & 0.019 & -0.036 & 0.087 \\
\hline $\mathrm{BOD}$ & 0.776 & 0.232 & -0.097 & 0.142 & 0.088 & 0.206 \\
\hline $\begin{array}{l}\text { Thermotolerant } \\
\text { coliforms }\end{array}$ & 0.648 & 0.079 & 0.089 & 0.283 & 0.331 & 0.226 \\
\hline COD & 0.621 & 0.646 & -0.013 & 0.231 & 0.033 & 0.102 \\
\hline Aluminium & 0.013 & 0.894 & 0.059 & 0.258 & -0.072 & 0.016 \\
\hline Lead & 0.176 & 0.734 & -0.202 & -0.297 & 0.131 & 0.066 \\
\hline Nickel & 0.002 & -0.036 & 0.844 & -0.038 & 0.137 & -0.126 \\
\hline $\mathrm{pH}$ & 0.459 & 0.003 & 0.536 & 0.118 & -0.386 & 0.154 \\
\hline Chrome & 0.080 & 0.003 & 0.048 & 0.836 & 0.070 & -0.074 \\
\hline Zinc & 0.193 & 0.324 & -0.134 & 0.506 & 0.036 & -0.423 \\
\hline Cyanide & 0.037 & -0.023 & 0.076 & 0.087 & 0.821 & 0.148 \\
\hline Phenol & 0.188 & 0.183 & -0.050 & -0.171 & 0.123 & 0.674 \\
\hline $\begin{array}{l}\text { Dissolved } \\
\text { oxygen }\end{array}$ & -0.453 & -0.206 & 0.480 & 0.186 & -0.438 & 0.113 \\
\hline Total solids & 0.198 & 0.300 & 0.210 & -0.089 & -0.143 & -0.335 \\
\hline $\begin{array}{l}\text { Water } \\
\text { temperature }\end{array}$ & 0.383 & 0.032 & 0.442 & -0.428 & 0.278 & -0.395 \\
\hline Total & 5.545 & 2.154 & 1.597 & 1.549 & 1.295 & 1.142 \\
\hline$\%$ Variance & 30.804 & 11.965 & 8.870 & 8.604 & 7.195 & 6.343 \\
\hline$\%$ Accumulated & 30.804 & 42.770 & 51.640 & 60.244 & 67.439 & 73.782 \\
\hline
\end{tabular}

*Variable rotation method: VARIMAX with Kaiser normalization.

The absence of certain parameters within the PC loads, such as dissolved oxygen, total solids and water temperature, can be indicative that the variance of these is more strongly interlinked to natural rather than anthropic processes. However, the importance of these in regard to maintaining environmental balance is unquestionable, and its monitoring and quantification should be considered in any project where water quality is being monitored.

Figure 2 illustrates the evolution of WQI of the rivers, during the three monitoring phases. Note that the points analysed presented a predominance of waters classified as regular and/or poor at all stages of monitoring. In moderate and highly urbanized areas, the result of poor water quality is a reflection of domestic sewage discharge in natura from point sources. Other point sources such as industry, which do not have adequate wastewater treatment, or do not meet the minimum discharge requirements, contribute significantly to this definition. 
Phase 1

(a)

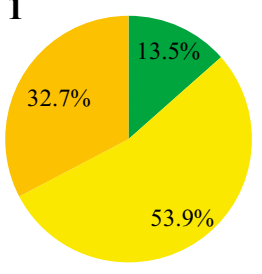

Phase 1

(b)

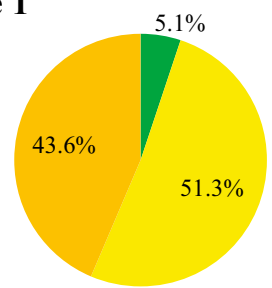

Phase 1

(c)

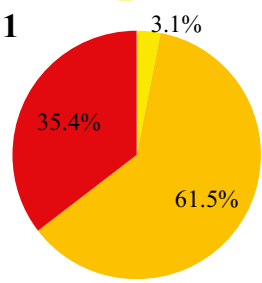

Phase 2
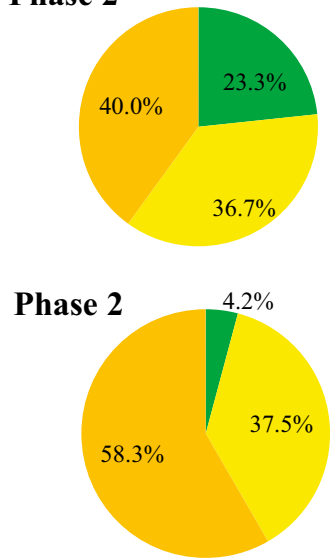

Phase 2

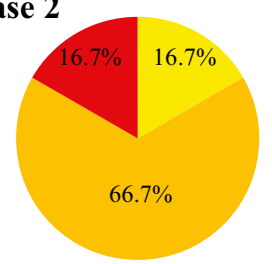

Phase 3
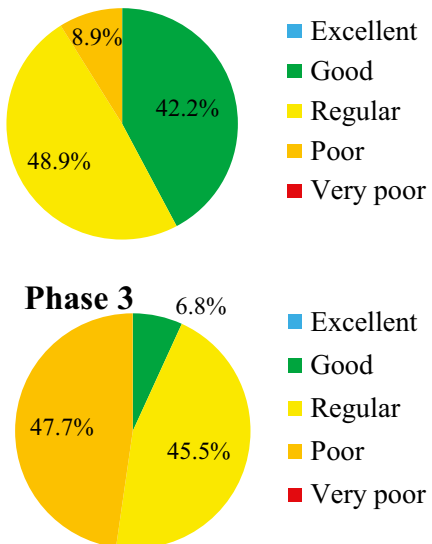

Phase 3

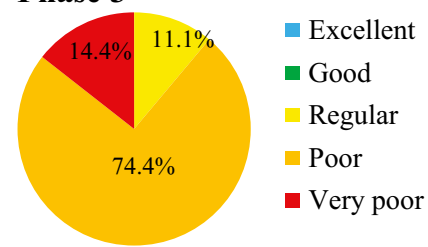

Figure 2: WQI evolution during monitoring. (a) Low degree of urbanization; (b) moderate degree of urbanization; and (c) high degree of urbanization.

At the same time, despite having lower domestic and industrial wastewater pressure, waters from areas with a low degree of urbanization were classified as regular and poor for most part of the monitoring period. The results showed that despite being located in peri-urban areas, water quality at these points suffer the influence from upstream urban areas. Here, it can be noted the presence of the self-purification process, even in small degree, given that the BOD concentration is mitigated at all points in these areas compared to those with a larger anthropic presence. Activities such as agriculture and livestock, which are characterized by their significant contribution of nutrients, also contribute to the variation of water quality at these sites.

An analysis considering only the results from the indexes in the monitoring phases demonstrates that there was an improvement in water quality over time (the WQI improves at the points of high and low degrees of urbanization). This may be influenced by the change of monitoring points between the three phases. However, it should be considered that the sewage service in the municipality (SAMAE) increased the percentage of sewage treated during the three phases. Figure 3 illustrates the evolution of TI in urban watersheds of Caxias do Sul, across the three monitoring phases.

Figure 3 shows the waters of Caxias do Sul are in risk with regard to the level of toxicity displayed. As expected, the points under a strong urban presence displayed high toxicity. It is interesting to note the sites with a lesser pressure from urbanization, likewise, demonstrated high levels of toxicity, particularly associated with nitrate, ammoniacal nitrogen, cyanide and phenol. The first two indicate the process of organic nitrogen degradation, originating from domestic sewage without treatment at points upstream [18]. Cyanide and phenol 
Phase 1

(a)

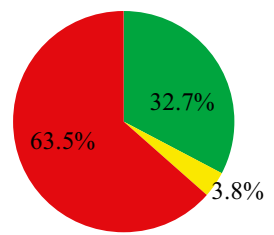

Phase 1

(b)

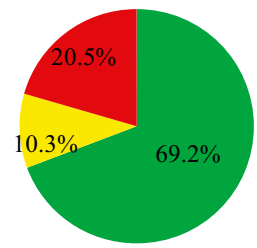

Phase 1

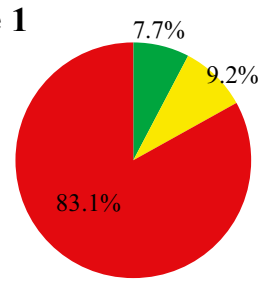

Phase 2

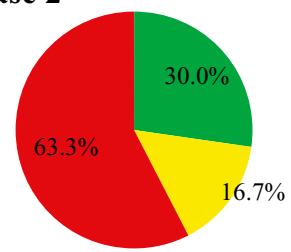

Phase 2

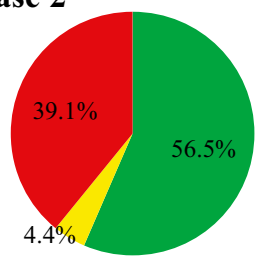

Phase 2

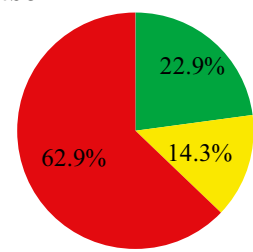

Phase 3

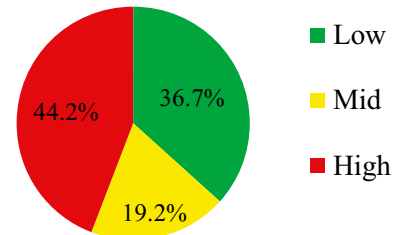

Phase 3

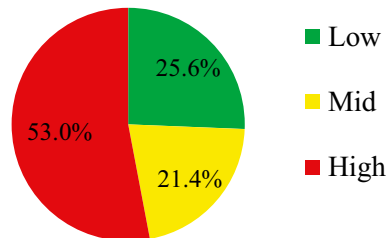

Phase $3 \quad 1.7 \%$

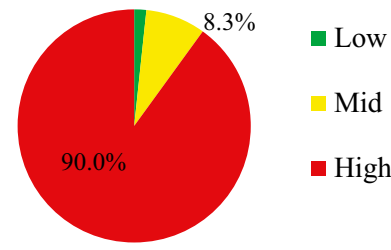

Figure 3: TI evolution during monitoring. (a) Low degree of urbanization; (b) moderate degree of urbanization; and (c) high degree of urbanization.

contamination may be associated with the transport of industrial areas located upstream, or even resulting from point application of agrochemicals.

The results exhibit some concerns in regard to the quality of municipal water. As there was no improvement of TI during the monitoring period, it can be inferred that actions such as the installation of a sewage treatment plant in the basin of Tega River (2012), among other non-structural improvements (licensing and environmental monitoring), did not generate the desired effect. Still, it is worth pointing out that basins such as those found in the Faxinal River and the Maestra Stream are located in catchment areas for public supply, and thus the parameters considered in the calculation of TI may be present in water which is provided to the population.

The overall CCME WQI results are presented in Fig. 4 and Table 8. A relevant point concerning the results of CCME WQI is that it affects a quality index that has as reference the class targets of where the river is situated. In other words, it is not a simple depiction of the quality such as with the WQI or the TI. Its interpretation should not be made considering only qualitative aspects, but also taking into account the goals proposed for the watershed commission.

The results presented in Fig. 3 show that the basin of the Tega River is the furthest away from its quality goals. The motives are diverse, being BOD, ammoniacal nitrogen, nitrate, phosphorus, thermotolerant coliforms, nickel, chromium, zinc, phenol and cyanide the parameters situated at furthest from the limits established for class 3, reflecting both domestic and industrial contamination. At some points of monitoring during phases 1 and 2, it was not possible to observe an improvement, indicating that quality problems are long-standing. 


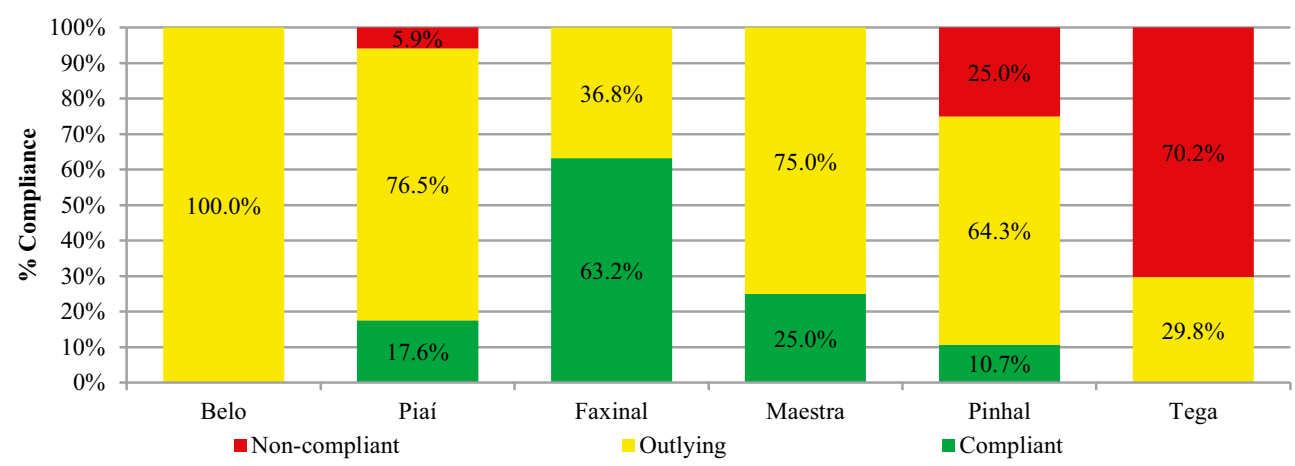

Figure 4: CCME WQI results in the urban basins during monitoring.

Moreover, even if it is possible to observe a slight improvement of the index values in the upstream-downstream direction, especially for parameters reflecting organic contamination, parameters such as nickel, chromium, phenol and cyanide decrease the CCME WQI in the basin, this being a reflection of the self-purification process.

A similar situation occurs with the watershed of the Pinhal stream. The CCME WQI results are likewise a reflection of both industrial and domestic water contamination, given the high level of urbanization in the upstream portion of the basin, in addition to greater restriction of the intermediate framework (Class 2) in relation to Tega River (Class 3). At points further away from the urban area, the CCME WQI presented compliance to the framework. However, there was a worsening in the quality of the stream, resulting from the presence of phenol, chrome and also an excess of BOD, resulting in a reduction of the index. This change seems to be related to the activities carried out in the district of Villa Cristina, the area drained by the water resource.

The Piaí River presents a peculiar situation, given that there are two quality targets in place for the river basin: Class 3 for the rivers of the western section and Class 1 for the rivers of the eastern section, this being evaluated only in phase 3 . Therefore, both the analysed points are outlying from the framework, with point 1 being in worse conditions (CCME WQI between 68.7 and 75.3) than point 2 (CCME WQI between 77.0 and 86.8). Point 1 has been presenting

Table 8: CCME WQI results of each watershed by the monitoring phase.

\begin{tabular}{llrrrrrr}
\hline Monitoring & Classification & $\begin{array}{r}\text { Belo } \\
(\boldsymbol{\%})\end{array}$ & $\begin{array}{r}\text { Piaí } \\
(\boldsymbol{\%})\end{array}$ & $\begin{array}{c}\text { Faxinal } \\
(\boldsymbol{\%})\end{array}$ & $\begin{array}{c}\text { Maestra } \\
(\boldsymbol{\%})\end{array}$ & $\begin{array}{c}\text { Pinhal } \\
(\boldsymbol{\%})\end{array}$ & $\begin{array}{c}\text { Tega } \\
(\boldsymbol{\%})\end{array}$ \\
\hline Phase 1 & Compliant & 0.0 & 0.0 & $*$ & 0.0 & 0.0 & 0.0 \\
& Outlying & 100.0 & 0.0 & $*$ & 100.0 & 0.0 & 40.0 \\
& Non-compliant & 0.0 & 100.0 & $*$ & 0.0 & 100.0 & 60.0 \\
\hline Phase 2 & Compliant & 0.0 & 0.0 & 0.0 & 0.0 & 0.0 & 0.0 \\
& Outlying & 100.0 & 100.0 & 100.0 & 100.0 & 100.0 & 57.1 \\
& Non-compliant & 0.0 & 0.0 & 0.0 & 0.0 & 0.0 & 42.9 \\
\hline Phase 3 & Compliant & 0.0 & 20.0 & 66.7 & 33.3 & 12.5 & 0.0 \\
& Outlying & 100.0 & 80.0 & 33.3 & 66.7 & 66.7 & 26.4 \\
& Non-compliant & 0.0 & 0.0 & 0.0 & 0.0 & 20.8 & 73.6 \\
\hline
\end{tabular}


a worsening quality since the analysis began. The other points of the watershed, located in streams with greater human impact, showed slight improvement during the monitoring. This evolution seems to be the result of improved treatment, or ending of activities of industries in the region. This becomes evident after observing that for both points, nickel was one of the elements which was largely responsible for the reduced CCME WQI values in phase 1, which was not found in point 3 and found substantially reduced in point 4.

The analysis of target achievements for Maestra and Faxinal Streams is relevant because two water supply springs are located within these watersheds. The Maestra River basin depicted low values of CCME WQI. It is worth noting that the monitoring point is located in a spring, which should present CCME WQI values above 90. The results therefore show evidence of faecal contamination (thermotolerant coliforms, BOD, phosphorus, nitrate and ammoniacal nitrogen). In Faxinal Stream was observed better water quality, especially in points 1 and 2, monitored during phase 3 and classified in all campaigns as in compliance. Though point 3 , analysed as of phase 2 , presents problems of faecal contamination, with high levels of thermotolerant coliforms, BOD, phosphorus, ammoniacal nitrogen and nitrate, it also presents problems of industrial contamination, as is evidenced by the presence of cyanide, phenol, and in one of the campaigns chrome. Throughout the entire period, the point is classified as an outlier.

The Belo watershed is classified throughout the entire monitoring period as outlying. The region of the springs presents high levels of urbanization, exposing their quality in the downstream direction. The quality problems revealed in the four monitored points are due to faecal contamination, with high values of phosphorus, coliforms and nitrogen (ammoniacal form in point 1 and nitrate in the others), but the presence of cyanide, phenol and nickel were also evident.

\section{CONCLUSIONS}

This study presented an analysis of data pertaining to the water quality in the city of Caxias do Sul, obtained from a monitoring programme whose goal is to provide decision makers subsidies for managing water resources. The analyses performed on the water quality data revealed watersheds containing higher levels of contamination, primarily due to the urban occupation. Also, it demonstrated the principal parameters and processes that impact rivers.

The application of PCA has shown that the component which explains most of the variation in water quality $(30.80 \%)$ is associated with domestic sewage lacking proper treatment. The main component includes parameters of conductivity, total Kjeldahl nitrogen, ammoniacal nitrogen, total phosphorus, BOD, thermotolerant coliforms and COD. The second component explained $29.44 \%$ of the water quality variation and suggests activities such as electroplating and metalworking impact the water quality. The other components show a strong dependence on industrial activities, in addition to certain agricultural activities when determining the quality of water.

The application of WQIs demonstrated similar results to the PCA. Factors such as the disposal of domestic and industrial effluents without proper levels of treatment significantly impact rivers in Caxias do Sul. The WQI and the TI exhibited such a situation for all watersheds, even including situations of great concern in relation to the public supply. The CCME WQI, in turn, showed how far the analysed basins are from the predicted framework goal, suggesting demand for proposed joint actions between the municipality and basin committees. 
The assessment of the compliance with the framework goals shows the effectiveness of this management tool is not achieved solely with the definition of usage classes. Once the monitoring results are compared with the quality standards set for each class, essential results were obtained to support the structuring of management actions on behalf of public officials in a municipality, whose sanitation characteristics resemble the vast majority of Brazilian municipalities, that is, having a low percentage of domestic sewage treatment, and ineffective discharge monitoring of industrial effluents.

Currently, one of the main challenges of water management is to control the impact the urban environment has on the natural environment. Studies such as this one significantly contribute, for example, to the establishment of environmental licensing criterion, by demonstrating patterns and characteristics of the environment, in addition to identifying which watersheds deserve greater attention with respect to control and recovery of environmental conditions. Further, studies such as this can provide support for revisions in Municipal Master Plans and Watershed Plans, especially with regard to qualitative aspects, thus avoiding conflicts over water use in future scenarios.

\section{REFERENCES}

[1] Vega, M., Pardo, R., Barrado, E. \& Deban, L., Assessment of seasonal and polluting effects on the quality of river water by exploratory data analysis. Water Research, 32(12), pp. 3581-3592, 1998. DOI: 10.1016/S0043-1354(98)00138-9.

[2] Almeida, M.A.B. \& Schwarzbold, A., Avaliação Sazonal da Qualidade das Águas do Arroio da Cria Montenegro, RS com Aplicação de um Índice de Qualidade de Água (IQA). Revista Brasileira de Recursos Hídricos, 8(1), pp. 81-97, 2003. DOI: 10.21168/ rbrh.v8n1.p81-97.

[3] Singh, K.P., Basant, A., Malik, A. \& Jain, G., Artificial neural network modeling of the river water quality - A case study. Ecological Modelling, 220(6), pp. 888-895, 2009. DOI: 10.1016/j.ecolmodel.2009.01.004.

[4] Bertossi, A.P.A., Cecílio, R.A., Neves, M.A. \& Garcia, G.O., Qualidade da água em microbacias hidrográficas com diferentes coberturas do solo no sul do Espirito Santo. Revista Árvore, 37(1), pp. 107-117, 2013. DOI: 10.1590/S1415-43662010000100008.

[5] Toledo, L.G. \& Nicolella, G., Índice de qualidade de água em microbacia sob uso agrícola e urbano. Scientia Agricola, 59(1), pp. 181-186, 2002. DOI: 10.2134/ jeq1998.00472425002700020006x.

[6] Fan, X., Cui, B., Zhao, H., Zhang, Z. \& Zhang, H., Assessment of river water quality in Pearl River Delta using multivariate statistical techniques. Procedia Environmental Sciences, 2, pp. 1220-1234, 2010. DOI: 10.1016/j.proenv.2010.10.133.

[7] Guedes, H.A.S., Silva, D.D., Elesbon, A.A.A., Ribeiro, C.B. M., Matos, A.T. \& Soares, J.H.P., Aplicação da análise estatística multivariada no estudo da qualidade da agua do Rio Pomba, MG. Revista Brasileira de Engenharia Agrícola e Ambiental, 15(5), pp. 558-563, 2012. DOI: 10.2134/jeq2004.0337.

[8] Damasceno, M. da C.S., Ribeiro, H.M.C., Takiyama, L.R. \& Paula, M.T. Avaliação sazonal da qualidade das águas superficiais do Rio Amazonas na orla da cidade de Macapá, Amapá, Brasil. Revista Ambiente e Água, 10(3), pp. 598-613, 2015. DOI: 10.4136/ambi-agua.1606.

[9] Instituto Brasileiro de Geografia e Estatística (IBGE), Gross domestic product - Brazil 2014, available at http://www.ibge.gov.br/english/estatistica/economia/pibmunicipios/2014/default.shtm, 2014 (accessed 25 August 2017). 
[10] Brasil. CONAMA Resolution 357, available at http://www.mma.gov.br/port/conama/ res/res05/res35705.pdf, 2005 (accessed 25 August 2017).

[11] Rio Grande do Sul. CRH Resolution 121, available at http://www.sema.rs.gov.br/ upload/arquivos/201708/22162317-resolucao-crh-121-2012-aprova-enquadramentoaguas-superficiais-bacia-taquari-antas-07-01-1.pdf, 2012(accessed 25 August 2017).

[12] Rio Grande do Sul. CRH Resolution 50, available at http://www.sema.rs.gov.br/upload/ arquivos/201708/22151357-resolucao-crh-50-2008-aprova-enquadramento-das-baciasdos-rios-cai-pardo-tramandai-e-lago-guaiba.pdf, 2008 (accessed 25 August 2017).

[13] Jolliffe, I.T. Principal Component Analysis, Springer-Verlag: New York, NY, 2002.

[14] Wang, X., Cai, Q., Ye, L. \& Qu, X., Evaluation of spatial and temporal variation in stream water quality by multivariate statistical techniques: A case study of the Xiangxi River basin, China. Quaternary International, 282, pp. 137-144, 2012. DOI: 10.1016/j. quaint.2012.05.015.

[15] Coletti, C., Testezlafl, R., Ribeiro, T.A.P., de Souza, R.T.G. \& Pereira, D. de A., Water quality index using multivariate factorial analysis. Revista Brasileira de Engenharia Agrícola e Ambiental, 14(5), pp. 517-522, 2009. DOI: 10.1590/S1415-43662010000500009.

[16] Pinto, U. \& Maheshwari, B.L., River health assessment in peri-urban landscapes: An application of multivariate analysis to identify the key variables. Water Research, 45(13), pp. 3915-3924, 2011. DOI: 10.1016/j.watres.2011.04.044.

[17] Companhia de Tecnologia de Saneamento Ambiental (CETESB), Relatório Anual de Qualidade das Águas Interiores no Estado de São Paulo, available at http://aguasinteriores.cetesb.sp.gov.br/wp-content/uploads/sites/32/2013/11/02.pdf, 2009 (accessed 25 August 2017).

[18] Von Sperling, M., Princípios do tratamento biológico de águas residuárias: Introdução à qualidade das águas e ao tratamento de esgotos, DESA-UFMG: Belo Horizonte, Brazil, 1996.

[19] Canadian Council of Ministers of the Environment (CCME), Water Quality Index: Technical Report. In: Canadian Water Quality Guidelines for the Protection of Aquatic Life, available at http://www.ccme.ca/files/Resources/calculators/WQI\%20User's\%20 Manual\%20(en).pdf, 2001 (accessed 25 August 2017).

[20] Cude, C.G., Oregon Water Quality Index a tool for evaluating water quality management effectiveness. Journal of the American Water Resources Association, 37(1), pp. 125-137, 2001. DOI: 10.1111/j.1752-1688.1978.tb02261.x.

[21] Terrado, M., Barceló, D., Tauler, R., Borrell, E., Campos, S. \& Barceló, D. Surface-water-quality indices for the analysis of data generated by automated sampling networks. Trends in Analytical Chemistry, 29(1), pp. 40-52, 2010. DOI: 10.1016/j. trac.2009.10.001.

[22] Hurley, T., Sadiq, R. \& Mazumder, A., Adaptation and evaluation of the Canadian Council of Ministers of the Environment Water Quality Index (CCME WQI) for use as an effective tool to characterize drinking source water quality. Water Research, 46(11), pp. 3544-3552, 2012. DOI: 10.1016/j.watres.2012.03.061.

[23] Abukila, A.F., Assessing the drain estuaries water quality in response to pollution abatement. Water Science, 29(1), pp. 1-18, 2015. DOI: 10.1016/j.wsj.2015.02.002.

[24] Amaro, C.A., Proposta de um índice para avaliação de conformidade da qualidade dos corpos hídricos ao enquadramento, available at www.teses.usp.br/teses/ disponiveis/3/3147/tde-11082009-121147/pt-br.php, 2009 (accessed 25 August 2017). 
[25] Agência Nacional das Águas (ANA), Panorama da Qualidade das Águas Superficiais do Brasil, ANA: Brasília, 2012.

[26] Liu, S., Manson, J.E., Stampfer, M.J., Hu, F.B., Giovannucci, E., Colditz, G.A., Hennekens, C,H. \& Willett, W.C., A prospective study of whole-grain intake and risk of type 2 diabetes mellitus in US women. American Journal of Public Health, 90(9) (1 September, 2000): pp. 1409-1415, 2003. DOI: 10.2105/AJPH.90.9.1409.

[27] Helena, B., Pardo, R., Vega, M., Barrado, E., Fernandez, J.M. \& Fernandez, L., Temporal evolution of groundwater composition in an alluvial aquifer (Pisuerga River, Spain) by principal component analysis. Water Research, 34, pp. 807-816, 2000. DOI: 10.1016/S0043-1354(99)00225-0. 